\title{
Hydrogen Sulfide Enhances Plant Tolerance to Waterlogging Stress
}

\author{
Yaoqi $\mathrm{Li}^{\dagger}$, Da Sun ${ }^{+}\left(\mathbb{D}, \mathrm{Ke} \mathrm{Xu}{ }^{*}\right.$, Libo Jin * and Renyi Peng * \\ Biomedicine Collaborative Innovation Center of Wenzhou, Engineering Laboratory of Zhejiang Province for \\ Pharmaceutical Development of Growth Factors, Institute of Life Sciences, Wenzhou University, \\ Wenzhou 325035, China; 20461337004@stu.wzu.edu.cn (Y.L.); 20170033@wzu.edu.cn (D.S.) \\ * Correspondence: godxu1987@163.com (K.X.); libo9518@126.com (L.J.); 20170032@wzu.edu.cn (R.P.) \\ † These authors contributed equally to this work.
}

Citation: Li, Y.; Sun, D.; Xu, K.; Jin, L.; Peng, R. Hydrogen Sulfide Enhances Plant Tolerance to Waterlogging Stress. Plants 2021, 10, 1928. https://doi.org/10.3390/ plants10091928

Academic Editor: Anis Limami

Received: 24 August 2021

Accepted: 13 September 2021

Published: 16 September 2021

Publisher's Note: MDPI stays neutral with regard to jurisdictional claims in published maps and institutional affiliations.

Copyright: (c) 2021 by the authors. Licensee MDPI, Basel, Switzerland. This article is an open access article distributed under the terms and conditions of the Creative Commons Attribution (CC BY) license (https:/ / creativecommons.org/licenses/by/ $4.0 /)$.

\begin{abstract}
Hydrogen sulfide $\left(\mathrm{H}_{2} \mathrm{~S}\right)$ is considered the third gas signal molecule in recent years. A large number of studies have shown that $\mathrm{H}_{2} \mathrm{~S}$ not only played an important role in animals but also participated in the regulation of plant growth and development and responses to various environmental stresses. Waterlogging, as a kind of abiotic stress, poses a serious threat to land-based waterlogging-sensitive plants, and which $\mathrm{H}_{2} \mathrm{~S}$ plays an indispensable role in response to. In this review, we summarized that $\mathrm{H}_{2} \mathrm{~S}$ improves resistance to waterlogging stress by affecting lateral root development, photosynthetic efficiency, and cell fates. Here, we reviewed the roles of $\mathrm{H}_{2} \mathrm{~S}$ in plant resistance to waterlogging stress, focusing on the mechanism of its promotion to gained hypoxia tolerance. Finally, we raised relevant issues that needed to be addressed.
\end{abstract}

Keywords: hydrogen sulfide; waterlogging; reactive oxygen species; gas signaling molecule; hypoxia tolerance

\section{Introduction}

Hydrogen sulfide $\left(\mathrm{H}_{2} \mathrm{~S}\right)$ is a colorless, toxic gas readily soluble in water with a pungent odor of rotten eggs [1,2]. It can be ionized to $\mathrm{H}^{+}, \mathrm{HS}^{-}$, and $\mathrm{S}^{2-}$ in aqueous solution; although the $\mathrm{HS}^{-}$cannot cross the cell membrane, $\mathrm{H}_{2} \mathrm{~S}$, acting as a small liposoluble molecule, is five times more soluble in lipophilic solvents than in water, can permeate the lipid membrane freely, because of $\mathrm{H}_{2} \mathrm{~S}^{\prime}$ s poor water solubility, it is difficult to long-distance transport; however, $\mathrm{SO}_{4}{ }^{2-}$ and sulfur compounds can be realized long-distance transport through xylem vessels to participate in endogenous $\mathrm{H}_{2} \mathrm{~S}$ metabolism in plant cells" [3-5]. $\mathrm{H}_{2} \mathrm{~S}$ is widely regarded as a harmful gas produced in industrial production until the middle of the late 1990s. The physiological role and importance of $\mathrm{H}_{2} \mathrm{~S}$ was gradually recognized by researchers. It was discovered that $\mathrm{H}_{2} \mathrm{~S}$ can be produced by mammals through cysteine metabolism. With the further study of $\mathrm{H}_{2} \mathrm{~S}$ as a gas signal molecule, many new physiological functions of $\mathrm{H}_{2} \mathrm{~S}$ - and $\mathrm{H}_{2} \mathrm{~S}$-induced effects are of increasing interest, and it is considered as the third gas signaling molecule, which can be produced internally and plays multiple physiological functions in plants and animals. In recent years, more and more excellent research works on $\mathrm{H}_{2} \mathrm{~S}$ have been done, and it is clearer and clearer to the mechanism of crosstalk between $\mathrm{H}_{2} \mathrm{~S}$ with other molecules to regulate plant growth and development $[2,6,7]$.

Water condition, affecting plant morphology, physiological, biochemical metabolism, and geographical distribution, is one of the important environmental factors for plant growth [8-11]. As the global warming, distribution of rainfall is seriously uneven, which leads to frequent waterlogging, and plant's growth and development are impacted, especially xerophytes $[9,12]$. During the waterlogging period, although most vascular plants were obviously damaged and even died, the main cause of waterlogging damage to plants is not the water itself but secondary stress induced by excessive water [13,14]. Researchers initially found that plants accumulate higher than normal levels of $\mathrm{H}_{2} \mathrm{~S}$ when exposed 
to stress. With the continuous in-depth study of the mechanism of stress response by many researchers, more and more evidence show that $\mathrm{H}_{2} \mathrm{~S}$ plays a very important and extensive role in many stress processes in plants, including hypoxic stress induced by waterlogging $[15,16]$.

A large number of studies have confirmed that $\mathrm{H}_{2} \mathrm{~S}$ participates in the regulation of plants response to drought [17-19], extreme temperature [20-23], high salt [24,25], ultraviolet light [26], high osmotic pressure [27-29] and heavy metal (cadmium, chromium, lead, copper, mercury, etc.) [30-38] and significantly improves the stress tolerance of plants. Because endogenous $\mathrm{H}_{2} \mathrm{~S}$ can be produced in plant cells, and $\mathrm{H}_{2} \mathrm{~S}^{\prime}$ s functions could be strengthened with the application of exogenous $\mathrm{H}_{2} \mathrm{~S}$. In order to study expediently, the application of $\mathrm{H}_{2} \mathrm{~S}$ donors to plants has become a common method, especially when $\mathrm{H}_{2} \mathrm{~S}$ responds to abiotic stresses. Waterlogging stress, which $\mathrm{H}_{2} \mathrm{~S}$ is involved in response to in plants, acts as abiotic stress with significant destructive power, and this review will focus on the role of $\mathrm{H}_{2} \mathrm{~S}$ as a signaling molecule in plant response to hypoxia stress induced by waterlogging $[3,39,40]$.

\section{The Role of $\mathrm{H}_{2} \mathrm{~S}$ in Response to Hypoxia Stress Induced by Waterlogging in Plants}

\subsection{Multiple Factors Affect Tolerance to Waterlogging Stress}

Waterlogging stress leads to the decrease in oxygen concentration in the rhizosphere of plants, resulting in the formation of hypoxia and anoxia. It directly acts on roots, making root hypoxia, nutrient absorption efficiency decreases, reduction in growth rate, further influences growth, and development of plants [41-44]. What is more, after a long period of evolution, plants have developed a series of stress response mechanisms. After sensing the anaerobic signal, a series of morphological, anatomical, physiological, and metabolic changes are caused by regulating the expression of genes so as to improve the ability to tolerate hypoxia and maintain the survival of individuals [45-49].

Plant waterlogging resistance is controlled by a combination of multiple factors [50-54]. The specific adaptive mechanism involves secondary signal transduction, gene expression, and protein synthesis, antioxidant enzyme system, and fermentation pathway under hypoxia stress [55-58]. Plants adapt to hypoxic stress from two aspects: avoidance and tolerance, that is, with promoting oxygen absorption and transport in vivo and reducing oxygen loss to escape hypoxic state, and with adjusting biochemical mechanisms to reduce the damage caused by hypoxia $[47,59,60]$ when $\mathrm{H}_{2} \mathrm{~S}$ acts a remarkable biological function in both these avoidance and adaptation strategies [6,61].

\subsection{Synthesis of $\mathrm{H}_{2} \mathrm{~S}$ in Plants}

Because of toxicity for the over-accumulation of $\mathrm{H}_{2} \mathrm{~S}$ in plant cells, different enzymes could be able to regulate the balance of $\mathrm{H}_{2} \mathrm{~S}$ content $[3,7,61,62]$. In mammals, $\mathrm{H}_{2} \mathrm{~S}$ production occurs in the cytoplasm and depends on the catalysis of enzymes, including cythione $-\beta$-synthase (CBS) and cythione- $\gamma$-lyase (CSE), in the sulfur-conversion pathway. On the one hand, CBS catalyzes the $\beta$-cysteine or homocysteine to produce cysteine and $\mathrm{H}_{2} \mathrm{~S}$. On the other hand, CSE, acting as a homologous tetramer enzyme, directly binds and catalyzes homocysteine and cysteine to product $\mathrm{H}_{2} \mathrm{~S}$. Additionally, 3-mercaptopyruvate thitransferase also contributes to the production of endogenous $\mathrm{H}_{2} \mathrm{~S}$ from 3-mercaptopyruvate [63]. However, the key plant $\mathrm{H}_{2} \mathrm{~S}$ synthases, named L/D-cysteine desulfhydrases (L/D-CDes), was first discovered in tobacco and gourd cells and mainly distributed in chloroplasts, mitochondria, and cytoplasm. Then, D-cysteine desulfhydrase (D-CDes) were identified and purified for the first time in Arabidopsis, which was found mainly based on homology characteristics similar to the D-CDes active protein in the large intestine. D-CDes are mainly located in the mitochondria, and their mRNA transcription level gradually increases plant growth and development but decreases during plant aging process. They also can catalyze the degradation of D-cysteine to produce $\mathrm{H}_{2} \mathrm{~S}$, pyruvate, and ammonia (Figure 1), and synthesis of $\mathrm{H}_{2} \mathrm{~S}$ can achieve self-regulation when plants face different 
needs such as growth, fruit ripening, diseases, and insect pests and abiotic stresses, and acquire regular growth and development or stress tolerance [64-67].

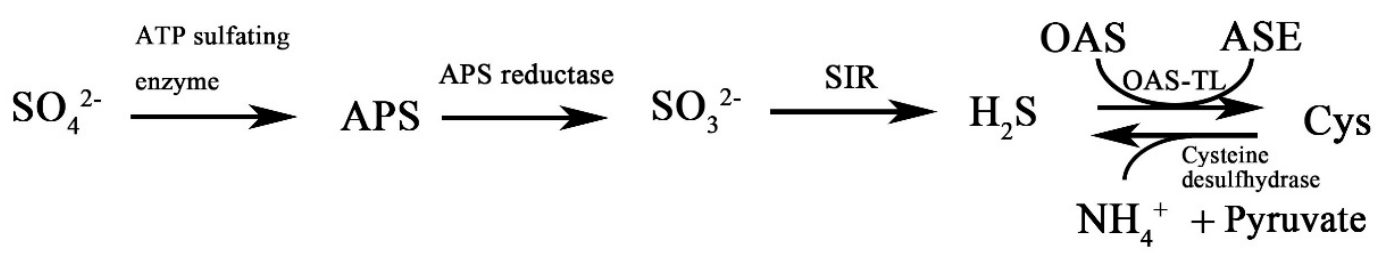

Figure 1. Synthesis of $\mathrm{H}_{2} \mathrm{~S}$ in plant cells [15]. APS: 5'-adenylylsulfate; SIR: sulfite reductase. OAS: O-acetyl serine; OAS-TL: O-acetyl-L-serine (mercaptan) lyase; ASE: acetate; Cys: cysteine.

\subsection{Intermediate Metabolite of $\mathrm{H}_{2} \mathrm{~S}$ in Plants Promotes Stress Tolerance}

The sulfur-containing defense system of plants includes elemental sulfur, $\mathrm{H}_{2} \mathrm{~S}$, glutathione (GSH), plant chelating agents, various secondary metabolites, and sulfur-rich proteins $[68,69] . \mathrm{SO}_{4}{ }^{2-}$ is absorbed and enters the vacuole to regulate the osmotic pressure of the cells, and some are transported to the aboveground part of the plant by high-affinity transporters and enters into the chloroplasts, chromoplasts, and other plastids to participate in the anabolism of $\mathrm{SO}_{3}{ }^{2-}$, these also could occur in the cytoplasm [70-73]. The formation of ASE and Cys from carrier compounds of $\mathrm{H}_{2} \mathrm{~S}$ or sulfur with OAS under OAS-TL can occur in both cytoplasm and mitochondria. The Cys is the metabolic precursor of glutathione, phytochemicals, and some sulfur-rich proteins, which is of great significance for the normal physiological activities of plants (Figure 2) [32,74].

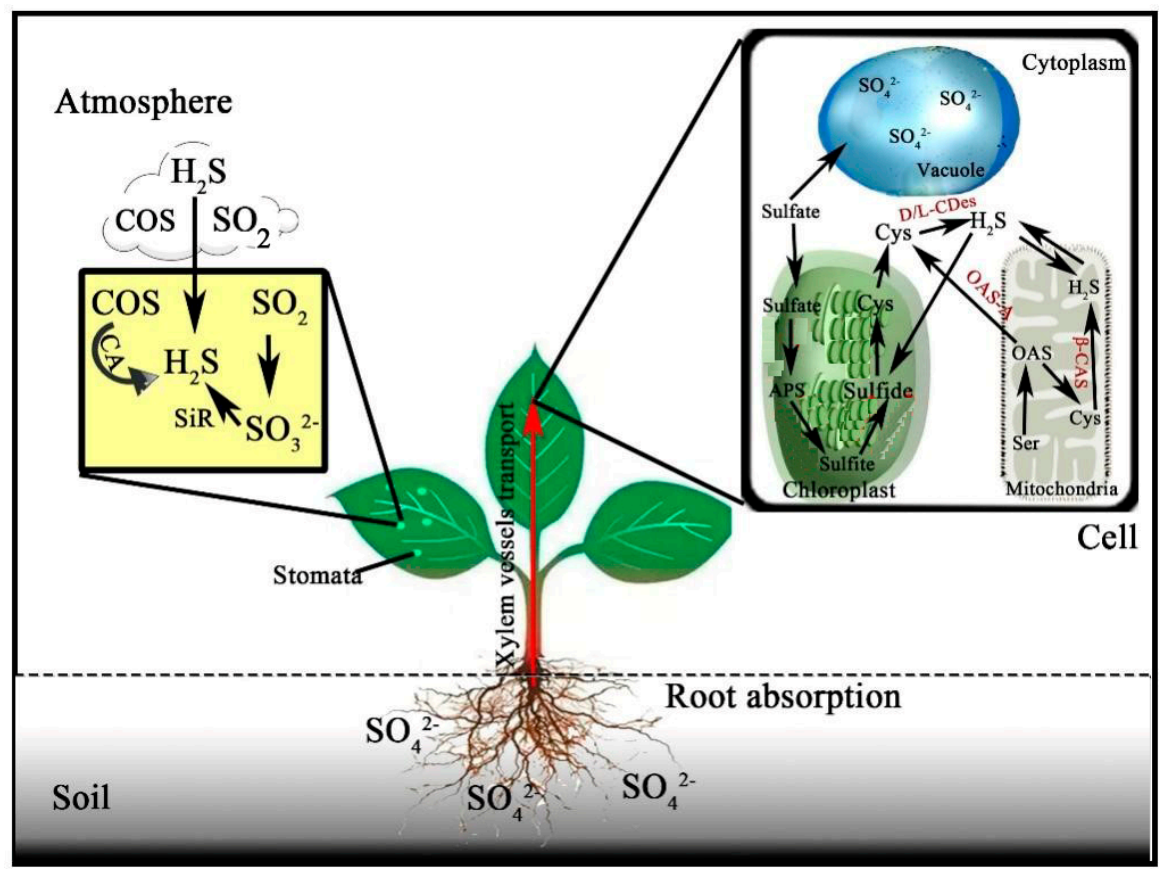

Figure 2. $\mathrm{H}_{2} \mathrm{~S}$ plays a pivotal role in sulfur metabolism in plants. Sulfur elements needed for sulfur metabolism in plants are mainly absorbed by roots in the manner of $\mathrm{SO}_{4}{ }^{2-}$ from the soil, which was transported to various parts of plants through microtubules to participate in the process of sulfur metabolism in plants. Another complementary pathway is the absorption of $\mathrm{H}_{2} \mathrm{~S}$, carbonyl sulfide (COS), and $\mathrm{SO}_{2}$ from the air through stomata on the leaves, thus immobilization of sulfur into the sulfur metabolic pathway in plants. CA: carbonic anhydrase, SiR: sulfite reductase.

Cysteine is also the metabolic precursor of many important molecular substances such as vitamins, cofactors, antioxidants, and many defense substances, and it could be further metabolized into other sulfur-rich proteins (SRPs), plant chelating peptides and 
GSH, and so on [72,75]. Meanwhile, O-acetylserine(thiol)lyase isoform a1 (OAS-A1), the main isozyme of OAS-TL, and L-cysteine desulfhydrase 1 (DES1), a cysteine-degrading cytoplasmic thiol enzyme, affected the homeostasis of cysteine in the cytoplasm. In this series of metabolites, $\mathrm{H}_{2} \mathrm{~S}$ is a very important intermediate product in the sulfur metabolism pathway, and sulfur metabolism has a significant impact on the stress adaptability of plants [76].

\section{Adventitious Root Formation, Photosynthesis Efficiency Improvement, Cell Death Alleviation Promoted by $\mathrm{H}_{2} \mathrm{~S}$ against Waterlogging Stress}

\section{1. $\mathrm{H}_{2} \mathrm{~S}$ Enhances the Occurrence of Adventitious Roots}

The occurrence of adventitious roots is one of the ways for plants to adapt to low oxygen stress in waterlogging [77-79]. $\mathrm{H}_{2} \mathrm{~S}$ produced by microorganisms in soil is little absorbed by roots for its poor water solubility, and the main pathway of $\mathrm{H}_{2} \mathrm{~S}$ accumulation is endogenous production in root cells. $\mathrm{H}_{2} \mathrm{~S}$ can promote the elongation of plant roots; for example, a low concentration of exogenous $\mathrm{H}_{2} \mathrm{~S}\left(0-40 \mu \mathrm{mol} \cdot \mathrm{L}^{-1}\right)$ can promote the growth of pea radicles and the formation of adventitious root formation in cucumber [80,81]. It was also found that the endogenous $\mathrm{H}_{2} \mathrm{~S}$, indoleacetic acid (IAA), and $\mathrm{NO}$ contents in sweet potato stem tip increased in sequence with the addition of $\mathrm{H}_{2} \mathrm{~S}$ donor sodium hydrosulfide (NaHS), suggesting that $\mathrm{H}_{2} \mathrm{~S}$ may induce adventive root formation through IAA and $\mathrm{NO}[67,82,83]$.

\section{2. $\mathrm{H}_{2} \mathrm{~S}$ Elevates the Photosynthetic Efficiency of Plants}

Photosynthetic efficiency is also an important reference index for the degree of hypoxia stress of plants subjected to waterlogging [84]. As early as 1973, Gassman reported that $\mathrm{H}_{2} \mathrm{~S}$ could break the disulfide bonds of photosystem proteins in yellow bean leaves and make them reversible. Then, much evidence showed that exogenous $\mathrm{H}_{2} \mathrm{~S}$ could increase the chlorophyll content of plant leaves $[85,86]$. For instance, $\mathrm{H}_{2} \mathrm{~S}$ increases the chlorophyll content of spinach leaves, changes the chloroplast structure, and improves the photosynthetic rate, which may be through the regulation of rubisco activity and the redox modification of sulfhydryl compounds to enhance photosynthesis [84]. Photosynthesis could be promoted with $\mathrm{H}_{2} \mathrm{~S}$ through promoting photosynthetic enzyme expression, chloroplast biogenesis, and thiol redox modification in Spinacia oleracea seedlings [19].

\section{3. $\mathrm{H}_{2} \mathrm{~S}$ Alleviates Plant Cell Death}

Cell is the basic constituent unit of the plant, whose surviving or not directly determines the survival state of plants during waterlogging [87]. Further, though the factors influencing cell survival include cytoplasmic redox state, $\mathrm{pH}$, energy supply, metabolic enzyme activity, programmed cell death factor, and many other factors, $\mathrm{H}_{2} \mathrm{~S}$ is generally involved in these physiological and biochemical processes $[3,88,89]$. Strawberries smoked with $\mathrm{H}_{2} \mathrm{~S}$ have been demonstrated that exogenous $\mathrm{H}_{2} \mathrm{~S}$ could maintain low rot index, high fruit firmness, low respiration density, and polygalacturonase activity, thus extending the fresh-keeping period of strawberries after picking [90]. There are studies that found that $\mathrm{H}_{2} \mathrm{~S}$ can reduce the plant tissue and cell death against hypoxia stress induced by waterlogging in pea, maize, and Arabidopsis, respectively [16,91,92].

\section{How $\mathrm{H}_{2} \mathrm{~S}$ Enhances the Hypoxia Tolerance of Plants during Waterlogging \\ 4.1. $\mathrm{H}_{2} \mathrm{~S}$ Enhances the Activity of Antioxidant System to Gain Waterlogging Tolerance}

Studies have shown that abnormal levels of reactive oxygen species (ROS) will be produced in plants subjected to stresses, resulting in oxidative damage of cells and some related key enzyme genes up-expression observably. Catalase (CAT), peroxidase (POD), and superoxide dismutase (SOD) are core members of the antioxidant enzyme system and have been recognized as key players in the complex signaling network in plants response to environmental stresses [93-95]. Previous studies showed that the activities of CAT, POD, and SOD were enhanced under mild waterlogging conditions, while their activities increased first and then decreased under severe waterlogging conditions [14]. 
Under waterlogging stress, the activities of POD and SOD in leaves of begonia seedlings increased significantly at the initial stage and then tended to be similar to the control [96]. The activities of key antioxidant enzymes in root tip cells of pea and maize treated with $\mathrm{H}_{2} \mathrm{~S}$ were significantly higher than untreated groups, and the degree of cell death was less than untreated groups, which was also reappeared in seedlings of Arabidopsis thaliana [91,92,97].

Reduced glutathione/oxidized glutathione (GSH/GSSG) is a meaningful parameter to reflect the redox state of cells (Figure 3) [98,99]. NaHS pretreatment could recover the loss of ascorbic acid (AsA) content and further increase the GSH content under extreme environmental conditions $[100,101]$. Furthermore, the content of GSH was further increased to maintain the ratio of AsA/dehydroascorbate (DHA) and GSH/GSSG, balance the content of mineral elements, reduce the absorption of $\mathrm{Na}^{+}$and the ratio of $\mathrm{Na}^{+} / \mathrm{K}^{+}$, and increase the endogenous $\mathrm{H}_{2} \mathrm{~S}$ content to protect chlorophyll, carotenoid and soluble proteins from oxidative damage [102,103]. It was found that NaHS up-regulates the activity of glyoxalase I (Gly I) and glyoxalase II (Gly II) enzymes related to glycine (Gly) metabolism in rice, thus maintaining the GSH system homeostasis and slowing down the cytotoxicity of methylglyoxal (MG) and ROS $[17,104]$. Oxidative damage caused by water stress could be alleviated by regulating ascorbic acid and glutathione metabolism resulting in alleviation of the impact of water stress on wheat seedlings $[68,105]$. It is worth noting that exogenous $\mathrm{NaHS}\left(\mathrm{H}_{2} \mathrm{~S}\right.$ donor) was applied to maize seedling roots inducing improvement of endogenous NO level in root tip cells, and NO acted as a second messenger to enhance the cyclic metabolism of AsA-GSH, maintained antioxidant system capacity, reduced ROS-induced macromolecular damage, and alleviated the damage caused by peroxidation to plants [106,107].

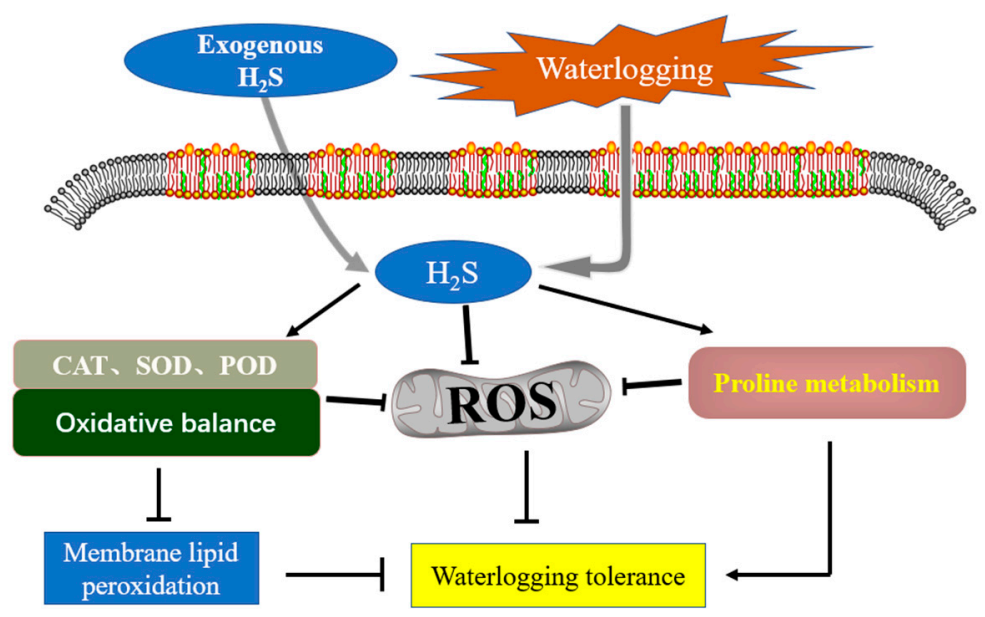

Figure 3. Schematic diagram of $\mathrm{H}_{2} \mathrm{~S}$ enhancing the activity of antioxidant system to acquire the tolerance to waterlogging-induced hypoxia.

\subsection{The Crosstalk between $\mathrm{H}_{2} \mathrm{~S}$ and Hormones Improves the Hypoxia Tolerance}

$\mathrm{H}_{2} \mathrm{~S}$ interaction with plant hormones withstands waterlogging-induced hypoxia stress. The physiological activities of higher plants are in a complex signal network, and there are different interactions between different pathways to jointly resist abiotic stress, and $\mathrm{H}_{2} \mathrm{~S}$ changes the balance of different signal substances and regulates plant growth and stress tolerance $[31,108]$. For example, salicylic acid (SA) is a phenol signaling substance that acts upstream of $\mathrm{H}_{2} \mathrm{~S}$ and participates in plants' response to stress [23,109]. Moreover, $\mathrm{H}_{2} \mathrm{~S}$ may be involved in the stomatal closure process induced by abscisic acid (ABA), ethylene and jasmonic acid (JA), and exogenous ABA can significantly improve the $\mathrm{H}_{2} \mathrm{~S}$ level and $\mathrm{L} / \mathrm{D}$-cysteine desulfhydrase activity in leaves, while $\mathrm{H}_{2} \mathrm{~S}$ synthesis inhibitors can reverse the effects of ABA $[17,110]$. In the study of maize seedlings, $\mathrm{H}_{2} \mathrm{~S}$ may act as a downstream signal molecule of $\mathrm{NO}$ to respond to waterlogging-induced hypoxia stress [92]. 


\section{3. $\mathrm{H}_{2} \mathrm{~S}$ Affects Respiratory Metabolism to Improve Hypoxia Stress Tolerance}

Respiration is the most basic source of power to maintain plant metabolism, growth, and transform nutrients. The plant root respiration is closely related to plant matter metabolism and energy metabolism, and the success of root respiration is one of the important indicators to measure plant root normal function and stress tolerance [40,111]. Malic dehydrogenase (MDH), phosphofructokinase (PFK), and glucose-6-phosphate dehydrogenase (G-6-PDH), whose activities directly affect the respiratory rate, are the key enzymes that regulate the rate of each respiratory metabolic pathway. Additionally, NaHS treatment of chestnut roots could improve the enzyme activities of MDH, PFK, and G-6-PDH to a certain extent, thus improving the stress tolerance of plants [84,112].

\subsection{Sulfur-Sulfhydrylation of Proteins by $\mathrm{H}_{2} \mathrm{~S}$ Strengthens Hypoxia Tolerance}

In plant cells, $\mathrm{H}_{2} \mathrm{~S}$ firstly modifies Cys residues with thiol, and then the Cys-SH group is transformed into the Cys-SSH sulfyl group, which directly regulates the activity of proteins [113]. $\mathrm{H}_{2} \mathrm{~S}$ induces changes in actin cytoskeleton and inhibits actin polymerization through s-vulcanization of actin, proving that $\mathrm{H}_{2} \mathrm{~S}$ regulates actin dynamics and affects root hair growth. Another study showed that exogenous $\mathrm{H}_{2} \mathrm{~S}$ promoted the sulfhydrylation of ascorbate peroxidase (APX) in Arabidopsis thaliana and improved its activity [72,114]. In conclusion, S-sulfhydrylation is an integrant pathway for an $\mathrm{H}_{2} \mathrm{~S}$ signaling molecule to exert biological activity in plants, and proteins, modified with sulfhydrylation, provide direct or indirect support for the acquisition of tolerance to low oxygen stress in waterlogging.

\section{5. $\mathrm{H}_{2} \mathrm{~S}$ Associating with $\mathrm{Ca}^{2+}$ Elevates Hypoxia Tolerance}

The increase in $\mathrm{Ca}^{2+}$ concentration is similar to the accumulation of ROS, which is one of the basic steps in plants' response to stress signals. Just like other signaling molecules, $\mathrm{Ca}^{2+}$ is a necessary universal second messenger acting as transduction and regulatory factor in plants, which can produce adaptive responses by $\mathrm{Ca}^{2+}$ binding proteins that sense rapid $\mathrm{Ca}^{2+}$ increase and transmit specific signals [115,116]. The reduction effect of $\mathrm{H}_{2} \mathrm{~S}$ is related to the promotion of $\mathrm{Ca}^{2+}$ influx, and $\mathrm{H}_{2} \mathrm{~S}$ generated by CBS was 3.5 times when there was $\mathrm{Ca}^{2+} /$ calmodulin (CaM) more than without them, while that can be inhibited with treating $\mathrm{CaM}$ inhibitors [117]. It has been reported that the application of exogenous $\mathrm{Ca}^{2+}$ and its ionic carrier A23187 could significantly enhance the antioxidant capacity induced by NaHS. However, $\mathrm{Ca}^{2+}$ chelating agents, ethylene glycol diethyl ether diamine tetraacetic acid (EGTA), plasma membrane channel blocker $\mathrm{La}^{3+}$, and calmodulin antagonist chlorpromazine and trifluoperazine can weaken this resistance [118].

\section{6. $\mathrm{H}_{2} \mathrm{~S}$ Involves in Regulating Gene Expression to Improve Tolerance to Waterlogging Stress}

The hypoxia stress of waterlogging, as one stress of plants response to, is regulated by many types of genes and involved many kinds of stress regulation processes [12,45,46]. $\mathrm{H}_{2} \mathrm{~S}$ up-regulated genes including SICDKA1, SICYCA2, CYCD3, CDKA1, ARF4, and ARF7 associated with cell cycle-related to lateral root growth in tomato seedlings, suggesting that $\mathrm{H}_{2} \mathrm{~S}$ and indoleacetic acid (IAA) jointly induced lateral root formation in tomato seedlings, which can enhance both drought resistance and waterlogging tolerance $[83,119]$. Transcriptomic sequencing of Arabidopsis thaliana pretreated with $\mathrm{H}_{2} \mathrm{~S}$ under hypoxia conditions found that significant changes related to transcription regulation-associated genes, hypoxia-sensing genes, and hormone signal transducer genes [16,54]. In addition, the accumulation of $\mathrm{H}_{2} \mathrm{~S}$ helps maize seedlings to enhance the waterlogging tolerance, during when the expression of related genes contained stress response, hypoxic induction, energy metabolism, and other changes remarkably [92].

Based on the above descriptions, enhancement of plant waterlogging tolerance involved in the regulation of $\mathrm{H}_{2} \mathrm{~S}$ was not determined by a single factor, but rather through gene expression, protein modification, regulation of plant hormones, and interaction with other signaling molecules, which were reflected in the reduction in cell death, enhancement of plant photosynthesis, formation of lateral roots at the macro level. In the future, through 
making full use of advanced gene editing and proteomics technology, the mechanism of $\mathrm{H}_{2} \mathrm{~S}$ participating in the regulation of plants to improve the waterlogging tolerance will be continuously improved.

\section{Conclusions and Perspectives}

The function of $\mathrm{H}_{2} \mathrm{~S}$ runs through the whole process of plant growth and development, and it is also indispensable in responding to hypoxic induced by waterlogging (Figure 4). In this review, we summarized the roles of $\mathrm{H}_{2} \mathrm{~S}$ in adventitious root formation, photosynthesis efficiency improvement, and cell death decrease in plants responding to waterlogging hypoxia stress and further discussed the specific approaches from the perspective of molecular mechanisms.

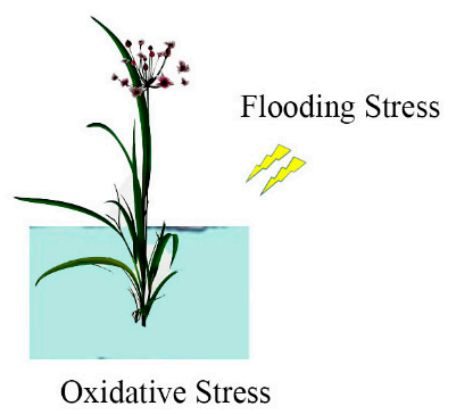

Decline of Photosynthesis

Ionic Imbalance

Membrane Injury

Energy Crisis

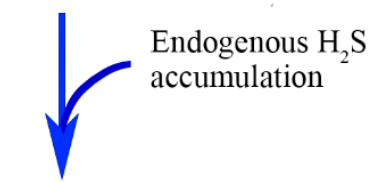

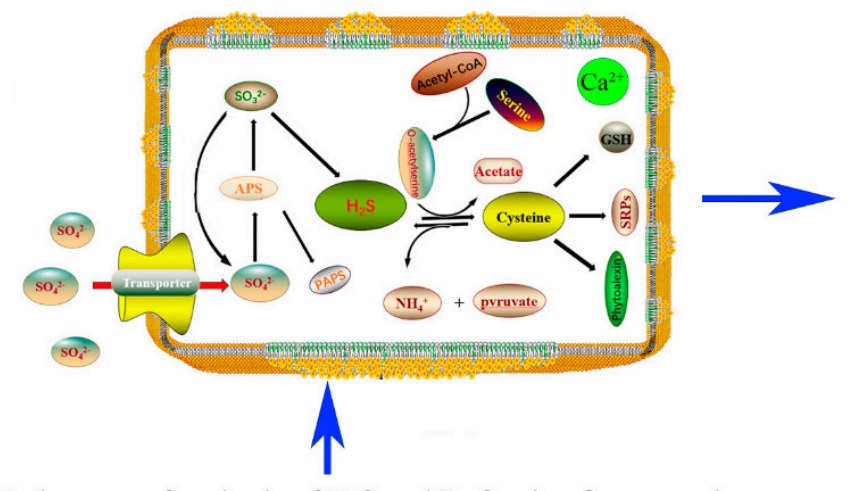

Endogenous Synthesis of $\mathrm{H}_{2} \mathrm{~S}$ and Defensive Compounds

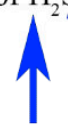

Cyanoalanine Synthase; Cysteine Desulfhydrase;

Sulphite reductase; Cysteine Synthase Expressing

Gene families

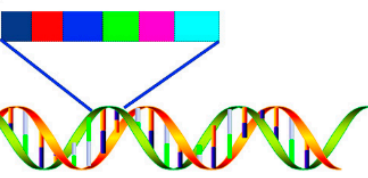

Gene Involved in $\mathrm{H}_{2} \mathrm{~S}$ Production
Antioxidant System

Membrane Integrity

Ionic Homeostasis

Metabolic Adaptations

Photosynthetic Adjustments
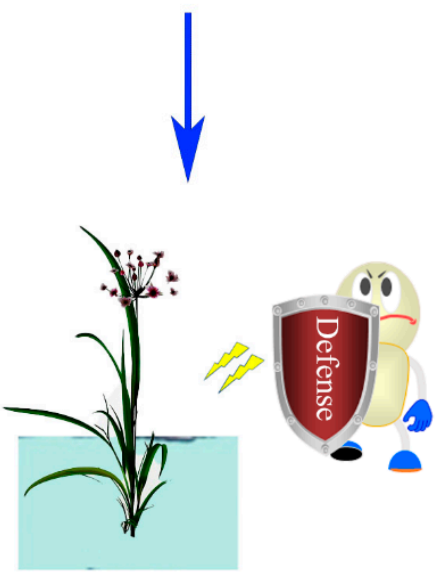

Flooding Stress Tolerance

Figure 4. The role of $\mathrm{H}_{2} \mathrm{~S}$ in the regulation of waterlogging stress in plants.

In spite of these advances in the exploration of $\mathrm{H}_{2} \mathrm{~S}$ 's response mechanism to hypoxia, many challenges remain. Firstly, the direct target, upstream and downstream cascade reaction of $\mathrm{H}_{2} \mathrm{~S}$ in the plant signal transduction process, and the crosstalk among $\mathrm{H}_{2} \mathrm{~S}$ and other signal molecules should be further elucidated. On the other hand, the process of plant response to hypoxia stress depends on the proportion of different hormones, of which $\mathrm{H}_{2} \mathrm{~S}$ may be the intermediate to coordinate the interaction, while whose mechanism is still not clear yet. However, with the continuous development of transgenic technology and gene-editing technology, we believe the molecular mechanism of $\mathrm{H}_{2} \mathrm{~S}$ involved in the regulation of hypoxia response is becoming increasingly clear.

Author Contributions: R.P., K.X. and L.J. contributed to the conception of this review. Y.L. and D.S. designed and produced the figures. R.P., Y.L. and D.S. wrote the manuscript. Y.L., L.J. and R.P. revised the manuscript. All authors read and approved the final manuscript.

Funding: This review was founded by the National Natural Science Foundation of China (51901160), Natural Science Foundation of Zhejiang Province (Grant No. LQ20C020003, LQ19E010004).

Institutional Review Board Statement: Not applicable. 
Informed Consent Statement: Not applicable.

Data Availability Statement: Not applicable.

Acknowledgments: We would also like to thank Qiong Nan at the University of Massachusetts Amherst for wrote and revised the manuscript.

Conflicts of Interest: The authors declare no conflict of interest.

\section{Abbreviations}

$\begin{array}{ll}\mathrm{H}_{2} \mathrm{~S} & \text { Hydrogen sulfide } \\ \text { NO } & \text { Nitric oxide } \\ \text { CO } & \text { Carbon monoxide } \\ \text { L/D-CDes } & \text { L/D-cysteine desulfhydrases } \\ \text { D-CDes } & \text { D-cysteine desulfhydrase } \\ \text { APS } & \text { 5'-adenylylsulfate } \\ \text { SIR } & \text { Sulfite reductase } \\ \text { OAS } & \text { O-acetyl serine } \\ \text { OAS-TL } & \text { O-acetyl-L-serine (mercaptan) lyase } \\ \text { ASE } & \text { Acetate } \\ \text { Cys } & \text { Cysteine } \\ \text { GSH } & \text { Glutathione } \\ \text { SRPs } & \text { Sulfur-rich proteins } \\ \text { OAS-A1 } & \text { O-acetylserine(thiol)lyase isoform a1 } \\ \text { DES1 } & \text { Desulfhydrase 1 } \\ \text { COS } & \text { Carbonyl sulfide } \\ \text { IAA } & \text { Indoleacetic acid } \\ \text { ROS } & \text { Reactive oxygen species } \\ \text { CAT } & \text { Catalase } \\ \text { POD } & \text { Peroxidase } \\ \text { SOD } & \text { Superoxide dismutase } \\ \text { GSH/GSSG } & \text { Glutathione/oxidized glutathione } \\ \text { AsA } & \text { Ascorbic acid } \\ \text { DHA } & \text { Dehydroascorbate } \\ \text { Gly I } & \text { Glyoxalase I } \\ \text { Gly II } & \text { Glyoxalase II } \\ \text { Gly } & \text { Glycine } \\ \text { MG } & \text { Methylglyoxal } \\ \text { SA } & \text { Salicylic acid } \\ \text { ABA } & \text { Abscisic acid } \\ \text { JA } & \text { Jasmonic acid } \\ \text { MDH } & \text { Malic dehydrogenase } \\ \text { PFK } & \text { Phosphofructokinase } \\ \text { G-6-PDH } & \text { Glucose-6-phosphate dehydrogenase } \\ \text { APX } & \text { Ascorbate peroxidase } \\ \text { CaM } & \text { Calmodulin } \\ \text { EGTA } & \end{array}$

\section{References}

1. Peng, Y.J.; Nanduri, J.; Raghuraman, G.; Souvannakitti, D.; Gadalla, M.M.; Kumar, G.K.; Snyder, S.H.; Prabhakar, N.R. H 2 S mediates $\mathrm{O}_{2}$ sensing in the carotid body. Proc. Natl. Acad. Sci. USA 2010, 107, 10719-10724. [CrossRef]

2. Zhang, H.; Hu, S.-L.; Zhang, Z.-J.; Hu, L.-Y.; Jiang, C.-X.; Wei, Z.-J.; Liu, J.; Wang, H.-L.; Jiang, S.-T. Hydrogen sulfide acts as a regulator of flower senescence in plants. Postharvest Biol. Technol. 2011, 60, 251-257. [CrossRef]

3. Li, Z.G.; Min, X.; Zhou, Z.H. Hydrogen Sulfide: A signal molecule in plant cross-adaptation. Front. Plant Sci. 2016, 7, 1621. [CrossRef]

4. Garcia-Mata, C.; Lamattina, L. Hydrogen sulphide, a novel gasotransmitter involved in guard cell signalling. New Phytol. 2010, 188, 977-984. [CrossRef] [PubMed]

5. Kamoun, P. Endogenous production of hydrogen sulfide in mammals. Amino Acids 2004, 26, 243-254. [CrossRef] [PubMed]

6. Hancock, J.T. Hydrogen sulfide and environmental stresses. Environ. Exp. Bot. 2019, 161, 50-56. [CrossRef] 
7. Zhang, J.; Zhou, M.; Zhou, H.; Zhao, D.; Gotor, C.; Romero, L.C.; Shen, J.; Ge, Z.; Zhang, Z.; Shen, W.; et al. Hydrogen sulfide, a signaling molecule in plant stress responses. J. Integr. Plant. Biol. 2021, 63, 146-160. [CrossRef]

8. Shkolnik-Inbar, D.; Bar-Zvi, D. ABI4 mediates abscisic acid and cytokinin inhibition of lateral root formation by reducing polar auxin transport in Arabidopsis. Plant Cell 2010, 22, 3560-3573. [CrossRef] [PubMed]

9. Murshed, R.; Lopez-Lauri, F.; Sallanon, H. Effect of water stress on antioxidant systems and oxidative parameters in fruits of tomato (Solanum lycopersicon L, cv. Micro-tom). Physiol. Mol. Biol. Plants 2013, 19, 363-378. [CrossRef]

10. Guo, Y.; Chen, J.; Kuang, L.; Wang, N.; Zhang, G.; Jiang, L.; Wu, D. Effects of waterlogging stress on early seedling development and transcriptomic responses in Brassica napus. Mol. Breed. 2020, 40,1-14. [CrossRef]

11. Mendiondo, G.M.; Gibbs, D.J.; Szurman-Zubrzycka, M.; Korn, A.; Marquez, J.; Szarejko, I.; Maluszynski, M.; King, J.; Axcell, B.; Smart, K.; et al. Enhanced waterlogging tolerance in barley by manipulation of expression of the N-end rule pathway E3 ligase PROTEOLYSIS6. Plant Biotechnol. J. 2016, 14, 40-50. [CrossRef]

12. Zaman, M.S.U.; Malik, A.I.; Erskine, W.; Kaur, P. Changes in gene expression during germination reveal pea genotypes with either "quiescence" or "escape" mechanisms of waterlogging tolerance. Plant Cell Environ. 2019, 42, 245-258. [CrossRef]

13. Cheng, Y.; Gu, M.; Cong, Y.; Zou, C.-s.; Zhang, X.-k.; Wang, H.-z. Combining ability and genetic effects of germination traits of brassica napus L. under Waterlogging Stress Condition. Agric. Sci. China 2010, 9, 951-957. [CrossRef]

14. Zou, X.-L.; Zeng, L.; Lu, G.-Y.; Cheng, Y.; Xu, J.-S.; Zhang, X.-K. Comparison of transcriptomes undergoing waterlogging at the seedling stage between tolerant and sensitive varieties of Brassica napus L. J. Integr. Agric. 2015, 14, 1723-1734. [CrossRef]

15. Xuan, L.; Li, J.; Wang, X.; Wang, C. Crosstalk between hydrogen sulfide and other signal molecules regulates plant growth and development. Int. J. Mol. Sci. 2020, 21, 4593. [CrossRef] [PubMed]

16. Yang, T.; Yuan, G.; Zhang, Q.; Xuan, L.; Li, J.; Zhou, L.; Shi, H.; Wang, X.; Wang, C. Transcriptome and metabolome analyses reveal the pivotal role of hydrogen sulfide in promoting submergence tolerance in Arabidopsis. Environ. Exp. Bot. 2021, 183, 104365. [CrossRef]

17. Zhou, H.; Chen, Y.; Zhai, F.; Zhang, J.; Zhang, F.; Yuan, X.; Xie, Y. Hydrogen sulfide promotes rice drought tolerance via reestablishing redox homeostasis and activation of ABA biosynthesis and signaling. Plant Physiol. Biochem. 2020, 155, 213-220. [CrossRef]

18. Li, L.H.; Yi, H.L.; Xiu-Ping, L.; Qi, H.X. Sulfur dioxide enhance drought tolerance of wheat seedlings through $\mathrm{H}_{2} \mathrm{~S}$ signaling. Ecotoxicol. Environ. Saf. 2021, 207, 111248. [CrossRef] [PubMed]

19. Chen, J.; Shang, Y.T.; Wang, W.H.; Chen, X.Y.; He, E.M.; Zheng, H.L.; Shangguan, Z. Hydrogen sulfide-mediated polyamines and sugar changes are involved in hydrogen sulfide-induced drought tolerance in Spinacia oleracea seedlings. Front. Plant Sci. 2016, 7, 1173. [CrossRef]

20. Pan, D.Y.; Fu, X.; Zhang, X.W.; Liu, F.J.; Bi, H.G.; Ai, X.Z. Hydrogen sulfide is required for salicylic acid-induced chilling tolerance of cucumber seedlings. Protoplasma 2020, 257, 1543-1557. [CrossRef] [PubMed]

21. Chen, Z.; Huang, Y.; Yang, W.; Chang, G.; Li, P.; Wei, J.; Yuan, X.; Huang, J.; Hu, X. The hydrogen sulfide signal enhances seed germination tolerance to high temperatures by retaining nuclear COP1 for HY5 degradation. Plant Sci. 2019, $285,34-43$. [CrossRef]

22. Zhou, Z.H.; Wang, Y.; Ye, X.Y.; Li, Z.G. Signaling molecule hydrogen sulfide improves seed germination and seedling growth of maize (Zea mays L.) under high temperature by inducing antioxidant system and osmolyte biosynthesis. Front. Plant Sci. 2018, 9, 1288. [CrossRef] [PubMed]

23. Li, Z.G. Synergistic effect of antioxidant system and osmolyte in hydrogen sulfide and salicylic acid crosstalk-induced heat tolerance in maize (Zea mays L.) seedlings. Plant Signal. Behav. 2015, 10, e1051278. [CrossRef]

24. Da-Silva, C.J.; Mollica, D.C.F.; Vicente, M.H.; Peres, L.E.P.; Modolo, L.V. NO, hydrogen sulfide does not come first during tomato response to high salinity. Nitric Oxide 2018, 76, 164-173. [CrossRef] [PubMed]

25. Kaya, C.; Higgs, D.; Ashraf, M.; Alyemeni, M.N.; Ahmad, P. Integrative roles of nitric oxide and hydrogen sulfide in melatonininduced tolerance of pepper (Capsicum annuum L.) plants to iron deficiency and salt stress alone or in combination. Physiol. Plant. 2020, 168, 256-277. [CrossRef] [PubMed]

26. Rostami, F.; Nasibi, F.; Manouchehri Kalantari, K. Alleviation of UV-B radiation damages by sodium hydrosulfide $\left(\mathrm{H}_{2} \mathrm{~S}\right.$ donor $)$ pre-treatment in Borage seedlings. J. Plant Interact. 2019, 14, 519-524. [CrossRef]

27. Zhu, J.K. Abiotic Stress Signaling and Responses in Plants. Cell 2016, 167, 313-324. [CrossRef]

28. Han, B.; Duan, X.; Wang, Y.; Zhu, K.; Zhang, J.; Wang, R.; Hu, H.; Qi, F.; Pan, J.; Yan, Y.; et al. Methane protects against polyethylene glycol-induced osmotic stress in maize by improving sugar and ascorbic acid metabolism. Sci. Rep. 2017, 7, 46185. [CrossRef]

29. Liu, Q.; Zhou, Y.; Li, H.; Liu, R.; Wang, W.; Wu, W.; Yang, N.; Wang, S. Osmotic stress-triggered stomatal closure requires Phospholipase D $\delta$ and hydrogen sulfide in Arabidopsis thaliana. Biochem. Biophys. Res. Commun. 2021, 534, 914-920. [CrossRef]

30. Li, Z.G. Analysis of some enzymes activities of hydrogen sulfide metabolism in plants. Methods Enzymol. 2015, 555, 253-269.

31. He, H.; Li, Y.; He, L.F. The central role of hydrogen sulfide in plant responses to toxic metal stress. Ecotoxicol. Environ. Saf. 2018, 157, 403-408. [CrossRef]

32. Fang, H.; Liu, Z.; Jin, Z.; Zhang, L.; Liu, D.; Pei, Y. An emphasis of hydrogen sulfide-cysteine cycle on enhancing the tolerance to chromium stress in Arabidopsis. Environ. Pollut. 2016, 213, 870-877. [CrossRef] [PubMed] 
33. Fang, H.; Jing, T.; Liu, Z.; Zhang, L.; Jin, Z.; Pei, Y. Hydrogen sulfide interacts with calcium signaling to enhance the chromium tolerance in Setaria italica. Cell Calcium 2014, 56, 472-481. [CrossRef] [PubMed]

34. Gu, Q.; Chen, Z.; Cui, W.; Zhang, Y.; Hu, H.; Yu, X.; Wang, Q.; Shen, W. Methane alleviates alfalfa cadmium toxicity via decreasing cadmium accumulation and reestablishing glutathione homeostasis. Ecotoxicol. Environ. Saf. 2018, 147, 861-871. [CrossRef] [PubMed]

35. Yang, X.; Kong, L.; Wang, Y.; Su, J.; Shen, W. Methane control of cadmium tolerance in alfalfa roots requires hydrogen sulfide. Environ. Pollut. 2021, 284, 117123. [CrossRef]

36. Rather, B.A.; Mir, I.R.; Sehar, Z.; Anjum, N.A.; Masood, A.; Khan, N.A. The outcomes of the functional interplay of nitric oxide and hydrogen sulfide in metal stress tolerance in plants. Plant Physiol. Biochem. 2020, 155, 523-534. [CrossRef]

37. Luo, S.; Calderón-Urrea, A.; Yu, J.; Liao, W.; Xie, J.; Lv, J.; Feng, Z.; Tang, Z. The role of hydrogen sulfide in plant alleviates heavy metal stress. Plant Soil 2020, 449, 1-10. [CrossRef]

38. Chen, Y.; Mo, H.Z.; Zheng, M.Y.; Xian, M.; Qi, Z.Q.; Li, Y.Q.; Hu, L.B.; Chen, J.; Yang, L.F. Selenium inhibits root elongation by repressing the generation of endogenous hydrogen sulfide in Brassica rapa. PLoS ONE 2014, 9, e110904. [CrossRef]

39. Yordanova, R. Antioxidative enzymes in barley plants subjected to soil flooding. Environ. Exp. Bot. 2004, 51, 93-101. [CrossRef]

40. Voesenek, L.A.; Sasidharan, R. Ethylene- and oxygen signalling-drive plant survival during flooding. Plant Biol. 2013, 15, 426-435. [CrossRef]

41. Sasidharan, R.; Voesenek, L.A. Ethylene-mediated acclimations to flooding stress. Plant Physiol. 2015, 169, 3-12. [CrossRef]

42. Licausi, F.; van Dongen, J.T.; Giuntoli, B.; Novi, G.; Santaniello, A.; Geigenberger, P.; Perata, P. HRE1 and HRE2, two hypoxiainducible ethylene response factors, affect anaerobic responses in Arabidopsis thaliana. Plant J. 2010, 62, 302-315. [CrossRef]

43. Bailey-Serres, J.; Fukao, T.; Gibbs, D.J.; Holdsworth, M.J.; Lee, S.C.; Licausi, F.; Perata, P.; Voesenek, L.A.; van Dongen, J.T. Making sense of low oxygen sensing. Trends Plant Sci. 2012, 17, 129-138. [CrossRef] [PubMed]

44. Pucciariello, C.; Perata, P. New insights into reactive oxygen species and nitric oxide signalling under low oxygen in plants. Plant Cell Environ. 2017, 40, 473-482. [CrossRef]

45. Valliyodan, B.; van Toai, T.T.; Alves, J.D.; de Fatima, P.G.P.; Lee, J.D.; Fritschi, F.B.; Rahman, M.A.; Islam, R.; Shannon, J.G.; Nguyen, H.T. Expression of root-related transcription factors associated with flooding tolerance of soybean (Glycine max). Int. J. Mol. Sci. 2014, 15, 17622-17643. [CrossRef] [PubMed]

46. Ruperti, B.; Botton, A.; Populin, F.; Eccher, G.; Brilli, M.; Quaggiotti, S.; Trevisan, S.; Cainelli, N.; Guarracino, P.; Schievano, E.; et al. Flooding responses on grapevine: A physiological, transcriptional, and metabolic perspective. Front. Plant Sci. $2019,10,339$. [CrossRef]

47. Loreti, E.; Perata, P. The Many Facets of Hypoxia in Plants. Plants 2020, 9, 745. [CrossRef]

48. Lothier, J.; Diab, H.; Cukier, C.; Limami, A.M.; Tcherkez, G. Metabolic responses to waterlogging differ between roots and shoots and reflect phloem transport alteration in Medicago truncatula. Plants 2020, 9, 1373. [CrossRef] [PubMed]

49. Sasidharan, R.; Mustroph, A. Plant oxygen sensing is mediated by the N-end rule pathway: A milestone in plant anaerobiosis. Plant Cell 2011, 23, 4173-4183. [CrossRef] [PubMed]

50. Licausi, F.; Kosmacz, M.; Weits, D.A.; Giuntoli, B.; Giorgi, F.M.; Voesenek, L.A.; Perata, P.; van Dongen, J.T. Oxygen sensing in plants is mediated by an N-end rule pathway for protein destabilization. Nature 2011, 479, 419-422. [CrossRef]

51. Hwang, S.T.; Li, H.; Alavilli, H.; Lee, B.H.; Choi, D. Molecular and physiological characterization of AtHIGD1 in Arabidopsis. Biochem. Biophys. Res. Commun. 2017, 487, 881-886. [CrossRef] [PubMed]

52. Li, Y.S.; Ou, S.L.; Yang, C.Y. The seedlings of different japonica rice varieties exhibit differ physiological properties to modulate plant survival rates under submergence stress. Plants 2020, 9, 982. [CrossRef] [PubMed]

53. Dat, J.F.; Capelli, N.; Folzer, H.; Bourgeade, P.; Badot, P.M. Sensing and signalling during plant flooding. Plant Physiol. Biochem. 2004, 42, 273-282. [CrossRef]

54. Van Veen, H.; Vashisht, D.; Akman, M.; Girke, T.; Mustroph, A.; Reinen, E.; Hartman, S.; Kooiker, M.; van Tienderen, P.; Schranz, M.E.; et al. Transcriptomes of eight Arabidopsis thaliana accessions reveal core conserved, genotype- and organ-specific responses to flooding stress. Plant Physiol. 2016, 172, 668-689. [CrossRef] [PubMed]

55. Hinz, M.; Wilson, I.W.; Yang, J.; Buerstenbinder, K.; Llewellyn, D.; Dennis, E.S.; Sauter, M.; Dolferus, R. Arabidopsis RAP2.2: An ethylene response transcription factor that is important for hypoxia survival. Plant Physiol. 2010, 153, 757-772. [CrossRef] [PubMed]

56. Parveen, M.; Asaeda, T.; Rashid, M.H. Biochemical adaptations of four submerged macrophytes under combined exposure to hypoxia and hydrogen sulphide. PLoS ONE 2017, 12, e0182691. [CrossRef]

57. Hartman, S.; Liu, Z.; van Veen, H.; Vicente, J.; Reinen, E.; Martopawiro, S.; Zhang, H.; van Dongen, N.; Bosman, F.; Bassel, G.W.; et al. Ethylene-mediated nitric oxide depletion pre-adapts plants to hypoxia stress. Nat. Commun. 2019, 10, 4020. [CrossRef]

58. Liu, F.; Vantoai, T.; Moy, L.P.; Bock, G.; Linford, L.D.; Quackenbush, J. Global transcription profiling reveals comprehensive insights into hypoxic response in Arabidopsis. Plant Physiol. 2005, 137, 1115-1129. [CrossRef]

59. Sepulveda-Garcia, E.B.; Pulido-Barajas, J.F.; Huerta-Heredia, A.A.; Pena-Castro, J.M.; Liu, R.; Barrera-Figueroa, B.E. Differential expression of maize and teosinte microRNAs under submergence, drought, and alternated stress. Plants 2020, 9, 1367. [CrossRef]

60. Buraschi, F.B.; Mollard, F.P.O.; Grimoldi, A.A.; Striker, G.G. Eco-physiological traits related to recovery from complete submergence in the model legume Lotus japonicus. Plants 2020, 9, 538. [CrossRef] 
61. Huang, D.; Huo, J.; Liao, W. Hydrogen sulfide: Roles in plant abiotic stress response and crosstalk with other signals. Plant Sci. 2021, 302, 110733. [CrossRef]

62. Zhao, M.; Liu, Q.; Zhang, Y.; Yang, N.; Wu, G.; Li, Q.; Wang, W. Alleviation of osmotic stress by $\mathrm{H}_{2} \mathrm{~S}$ is related to regulated PLDalpha1 and suppressed ROS in Arabidopsis thaliana. J. Plant Res. 2020, 133, 393-407. [CrossRef]

63. Chen, H.J.; Ngowi, E.E.; Qian, L.; Li, T.; Qin, Y.Z.; Zhou, J.J.; Li, K.; Ji, X.Y.; Wu, D.D. Role of hydrogen sulfide in the endocrine system. Front. Endocrinol. 2021, 12, 704620. [CrossRef]

64. Alvarez, C.; Garcia, I.; Moreno, I.; Perez-Perez, M.E.; Crespo, J.L.; Romero, L.C.; Gotor, C. Cysteine-generated sulfide in the cytosol negatively regulates autophagy and modulates the transcriptional profile in Arabidopsis. Plant Cell 2012, 24, 4621-4634. [CrossRef] [PubMed]

65. Yamasaki, H.; Ogura, M.P.; Kingjoe, K.A.; Cohen, M.F. d-Cysteine-induced rapid root abscission in the water fern azolla pinnata: Implications for the linkage between d-amino acid and reactive sulfur species (RSS) in plant environmental responses. Antioxidants 2019, 8, 411. [CrossRef]

66. Romero, L.C.; Garcia, I.; Gotor, C. L-Cysteine desulfhydrase 1 modulates the generation of the signaling molecule sulfide in plant cytosol. Plant Signal. Behav. 2013, 8, e24007. [CrossRef]

67. Mei, Y.; Zhao, Y.; Jin, X.; Wang, R.; Xu, N.; Hu, J.; Huang, L.; Guan, R.; Shen, W. L-Cysteine desulfhydrase-dependent hydrogen sulfide is required for methane-induced lateral root formation. Plant Mol. Biol. 2019, 99, 283-298. [CrossRef]

68. Shan, C.-J.; Zhang, S.-L.; Li, D.-F.; Zhao, Y.-Z.; Tian, X.-L.; Zhao, X.-L.; Wu, Y.-X.; Wei, X.-Y.; Liu, R.-Q. Effects of exogenous hydrogen sulfide on the ascorbate and glutathione metabolism in wheat seedlings leaves under water stress. Acta Physiol. Plant. 2011, 33, 2533-2540. [CrossRef]

69. Xie, Y.; Zhang, C.; Lai, D.; Sun, Y.; Samma, M.K.; Zhang, J.; Shen, W. Hydrogen sulfide delays GA-triggered programmed cell death in wheat aleurone layers by the modulation of glutathione homeostasis and heme oxygenase-1 expression. J. Plant Physiol. 2014, 171, 53-62. [CrossRef] [PubMed]

70. Mancardi, D.; Penna, C.; Merlino, A.; del Soldato, P.; Wink, D.A.; Pagliaro, P. Physiological and pharmacological features of the novel gasotransmitter: Hydrogen sulfide. Biochim. Biophys. Acta 2009, 1787, 864-872. [CrossRef] [PubMed]

71. He, H.; Li, Y.; He, L.F. Role of nitric oxide and hydrogen sulfide in plant aluminum tolerance. Biometals 2019, 32, 1-9. [CrossRef] [PubMed]

72. Aroca, A.; Serna, A.; Gotor, C.; Romero, L.C. S-sulfhydration: A cysteine posttranslational modification in plant systems. Plant Physiol. 2015, 168, 334-342. [CrossRef]

73. Gotor, C.; Garcia, I.; Crespo, J.L.; Romero, L.C. Sulfide as a signaling molecule in autophagy. Autophagy 2013, 9, 609-611. [CrossRef]

74. Liu, H.; Wang, J.; Liu, J.; Liu, T.; Xue, S. Hydrogen sulfide $\left(\mathrm{H}_{2} \mathrm{~S}\right)$ signaling in plant development and stress responses. Abiotech 2021, 2, 1-32. [CrossRef]

75. Ma, Q.; Hill, P.W.; Chadwick, D.R.; Wu, L.; Jones, D.L. Competition for S-containing amino acids between rhizosphere microorganisms and plant roots: The role of cysteine in plant $S$ acquisition. Biol. Fertil. Soils 2021, 57, 825-836. [CrossRef]

76. Khan, M.N.; Al Zuaibr, F.M.; Al-Huqail, A.A.; Siddiqui, M.H.; Ali, H.M.; Al-Muwayhi, M.A.; Al-Haque, H.N. Hydrogen sulfide-mediated activation of $o$-acetylserine (Thiol) lyase and $1 / \mathrm{d}$-cysteine desulfhydrase enhance dehydration tolerance in eruca sativa mill. Int. J. Mol. Sci. 2018, 19, 3981. [CrossRef] [PubMed]

77. Hartman, S.; van Dongen, N.; Renneberg, D.; Welschen-Evertman, R.A.M.; Kociemba, J.; Sasidharan, R.; Voesenek, L. Ethylene differentially modulates hypoxia responses and tolerance across solanum species. Plants 2020, 9, 1022. [CrossRef] [PubMed]

78. Shukla, V.; Lombardi, L.; Pencik, A.; Novak, O.; Weits, D.A.; Loreti, E.; Perata, P.; Giuntoli, B.; Licausi, F. Jasmonate signalling contributes to primary root inhibition upon oxygen deficiency in Arabidopsis thaliana. Plants 2020, 9, 1046. [CrossRef] [PubMed]

79. Salvatierra, A.; Toro, G.; Mateluna, P.; Opazo, I.; Ortiz, M.; Pimentel, P. Keep calm and survive: Adaptation strategies to energy crisis in fruit trees under root hypoxia. Plants 2020, 9, 1108. [CrossRef]

80. Lin, Y.-T.; Li, M.-Y.; Cui, W.-T.; Lu, W.; Shen, W.-B. Haem oxygenase-1 is involved in hydrogen sulfide-induced cucumber adventitious root formation. J. Plant Growth Regul. 2012, 31, 519-528. [CrossRef]

81. Lin, Y.; Zhang, W.; Qi, F.; Cui, W.; Xie, Y.; Shen, W. Hydrogen-rich water regulates cucumber adventitious root development in a heme oxygenase-1/carbon monoxide-dependent manner. J. Plant Physiol. 2014, 171, 1-8. [CrossRef]

82. Fang, T.; Cao, Z.; Li, J.; Shen, W.; Huang, L. Auxin-induced hydrogen sulfide generation is involved in lateral root formation in tomato. Plant Physiol. Biochem. 2014, 76, 44-51. [CrossRef] [PubMed]

83. Mei, Y.; Chen, H.; Shen, W.; Shen, W.; Huang, L. Hydrogen peroxide is involved in hydrogen sulfide-induced lateral root formation in tomato seedlings. BMC Plant Biol. 2017, 17, 162. [CrossRef] [PubMed]

84. Chen, J.; Wu, F.H.; Wang, W.H.; Zheng, C.J.; Lin, G.H.; Dong, X.J.; He, J.X.; Pei, Z.M.; Zheng, H.L. Hydrogen sulphide enhances photosynthesis through promoting chloroplast biogenesis, photosynthetic enzyme expression, and thiol redox modification in Spinacia oleracea seedlings. J. Exp. Bot. 2011, 62, 4481-4493. [CrossRef]

85. Zhang, H.; Ye, Y.-K.; Wang, S.-H.; Luo, J.-P.; Tang, J.; Ma, D.-F. Hydrogen sulfide counteracts chlorophyll loss in sweetpotato seedling leaves and alleviates oxidative damage against osmotic stress. J. Plant Growth Regul. 2009, 58, 243-250. [CrossRef]

86. Hu, H.; Liu, D.; Li, P.; Shen, W. Hydrogen sulfide delays leaf yellowing of stored water spinach (Ipomoea aquatica) during dark-induced senescence by delaying chlorophyll breakdown, maintaining energy status and increasing antioxidative capacity. Postharvest Biol. Technol. 2015, 108, 8-20. [CrossRef] 
87. Loreti, E.; van Veen, H.; Perata, P. Plant responses to flooding stress. Curr. Opin. Plant Biol. 2016, 33, 64-71. [CrossRef]

88. Banerjee, A.; Tripathi, D.K.; Roychoudhury, A. Hydrogen sulphide trapeze: Environmental stress amelioration and phytohormone crosstalk. Plant Physiol. Biochem. 2018, 132, 46-53. [CrossRef]

89. Gil-Monreal, M.; Royuela, M.; Zabalza, A. Hypoxic treatment decreases the physiological action of the herbicide imazamox on pisum sativum roots. Plants 2020, 9, 981. [CrossRef]

90. Zhu, L.; Wang, W.; Shi, J.; Zhang, W.; Shen, Y.; Du, H.; Wu, S. Hydrogen sulfide extends the postharvest life and enhances antioxidant activity of kiwifruit during storage. J. Sci. Food Agric. 2014, 94, 2699-2704. [CrossRef]

91. Cheng, W.; Zhang, L.; Jiao, C.; Su, M.; Yang, T.; Zhou, L.; Peng, R.; Wang, R.; Wang, C. Hydrogen sulfide alleviates hypoxia-induced root tip death in Pisum sativum. Plant Physiol. Biochem. 2013, 70, 278-286. [CrossRef]

92. Peng, R.; Bian, Z.; Zhou, L.; Cheng, W.; Hai, N.; Yang, C.; Yang, T.; Wang, X.; Wang, C. Hydrogen sulfide enhances nitric oxide-induced tolerance of hypoxia in maize (Zea mays L.). Plant Cell Rep. 2016, 35, 2325-2340. [CrossRef]

93. You, J.; Chan, Z. ROS regulation during abiotic stress responses in arop plants. Front. Plant Sci. 2015, 6, 1092. [CrossRef]

94. Liu, Y.; He, C. Regulation of plant reactive oxygen species (ROS) in stress responses: Learning from AtRBOHD. Plant Cell Rep. 2016, 35, 995-1007. [CrossRef]

95. Filomeni, G.; Desideri, E.; Cardaci, S.; Rotilio, G.; Ciriolo, M.R. Under the ROS: Thiol network is the principal suspect for autophagy commitment. Autophagy 2010, 6, 999-1005. [CrossRef] [PubMed]

96. Xu, M.; Ma, H.; Zeng, L.; Cheng, Y.; Lu, G.; Xu, J.; Zhang, X.; Zou, X. The effect of waterlogging on yield and seed quality at the early flowering stage in Brassica napus L. Field Crops Res. 2015, 180, 238-245. [CrossRef]

97. Lin, X.; Yang, R.; Dou, Y.; Zhang, W.; Du, H.; Zhu, L.; Chen, J. Transcriptome analysis reveals delaying of the ripening and cell-wall degradation of kiwifruit by hydrogen sulfide. J. Sci. Food Agric. 2020, 100, 2280-2287. [CrossRef]

98. Hancock, J.T.; Whiteman, M. Hydrogen sulfide signaling: Interactions with nitric oxide and reactive oxygen species. Ann. N. Y. Acad. Sci. 2016, 1365, 5-14. [CrossRef] [PubMed]

99. Bratt, A.; Rosenwasser, S.; Meyer, A.; Fluhr, R. Organelle redox autonomy during environmental stress. Plant Cell Environ. 2016, 39, 1909-1919. [CrossRef]

100. Penella, C.; Calatayud, A.; Melgar, J.C. Ascorbic acid alleviates water stress in young peach trees and improves their performance after rewatering. Front. Plant Sci. 2017, 8, 1627. [CrossRef]

101. Gill, S.S.; Tuteja, N. Reactive oxygen species and antioxidant machinery in abiotic stress tolerance in crop plants. Plant Physiol. Biochem. 2010, 48, 909-930. [CrossRef] [PubMed]

102. Mostofa, M.G.; Saegusa, D.; Fujita, M.; Tran, L.S. Hydrogen sulfide regulates salt tolerance in rice by maintaining $\mathrm{Na}\left({ }^{+}\right) / \mathrm{K}\left({ }^{+}\right)$ balance, mineral homeostasis and oxidative metabolism under excessive salt stress. Front. Plant Sci. 2015, 6, 1055. [CrossRef]

103. Zhao, N.; Zhu, H.; Zhang, H.; Sun, J.; Zhou, J.; Deng, C.; Zhang, Y.; Zhao, R.; Zhou, X.; Lu, C.; et al. Hydrogen sulfide mediates $\mathrm{K}\left({ }^{+}\right)$and $\mathrm{Na}\left({ }^{+}\right)$homeostasis in the roots of salt-resistant and salt-sensitive poplar species subjected to NaCl stress. Front. Plant Sci. 2018, 9, 1366. [CrossRef]

104. Steffens, B.; Sauter, M. Epidermal cell death in rice is confined to cells with a distinct molecular identity and is mediated by ethylene and $\mathrm{H}_{2} \mathrm{O}_{2}$ through an autoamplified signal pathway. Plant Cell 2009, 21, 184-196. [CrossRef]

105. Yemelyanov, V.V.; Chirkova, T.V.; Shishova, M.F.; Lindberg, S.M. Potassium efflux and cytosol acidification as primary anoxiainduced events in wheat and rice seedlings. Plants 2020, 9, 1216. [CrossRef]

106. Kimura, $\mathrm{H}$. Hydrogen polysulfide $\left(\mathrm{H}_{2} \mathrm{Sn}\right)$ signaling along with hydrogen sulfide $\left(\mathrm{H}_{2} \mathrm{~S}\right)$ and nitric oxide (NO). J. Neural Transm. 2016, 123, 1235-1245. [CrossRef] [PubMed]

107. Zhang, P.; Luo, Q.; Wang, R.; Xu, J. Hydrogen sulfide toxicity inhibits primary root growth through the ROS-NO pathway. Sci. Rep. 2017, 7, 868. [CrossRef]

108. Lai, D.; Mao, Y.; Zhou, H.; Li, F.; Wu, M.; Zhang, J.; He, Z.; Cui, W.; Xie, Y. Endogenous hydrogen sulfide enhances salt tolerance by coupling the reestablishment of redox homeostasis and preventing salt-induced $\left.\mathrm{K}^{+}\right)$loss in seedlings of Medicago sativa. Plant Sci. 2014, 225, 117-129. [CrossRef]

109. Li, Z.G.; Xie, L.R.; Li, X.J. Hydrogen sulfide acts as a downstream signal molecule in salicylic acid-induced heat tolerance in maize (Zea mays L.) seedlings. J. Plant Physiol. 2015, 177, 121-127. [CrossRef] [PubMed]

110. Cutler, S.R.; Rodriguez, P.L.; Finkelstein, R.R.; Abrams, S.R. Abscisic acid: Emergence of a core signaling network. Annu. Rev. Plant Biol. 2010, 61, 651-679. [CrossRef]

111. Gibbs, D.J.; Lee, S.C.; Isa, N.M.; Gramuglia, S.; Fukao, T.; Bassel, G.W.; Correia, C.S.; Corbineau, F.; Theodoulou, F.L.; Bailey-Serres, J.; et al. Homeostatic response to hypoxia is regulated by the N-end rule pathway in plants. Nature 2011, 479, 415-418. [CrossRef] [PubMed]

112. Hu, L.Y.; Hu, S.L.; Wu, J.; Li, Y.H.; Zheng, J.L.; Wei, Z.J.; Liu, J.; Wang, H.L.; Liu, Y.S.; Zhang, H. Hydrogen sulfide prolongs postharvest shelf life of strawberry and plays an antioxidative role in fruits. J. Agric. Food Chem. 2012, 60, 8684-8693. [CrossRef] [PubMed]

113. Paul, B.D.; Snyder, S.H. $\mathrm{H}_{2} \mathrm{~S}$ signalling through protein sulfhydration and beyond. Nat. Rev. Mol. Cell Biol. $2012,13,499-507$. [CrossRef]

114. Aroca, A.; Gotor, C.; Romero, L.C. Hydrogen sulfide signaling in plants: Emerging roles of protein persulfidation. Front. Plant Sci. 2018, 9, 1369. [CrossRef] 
115. Ma, Y.; Wang, P.; Gu, Z.; Tao, Y.; Shen, C.; Zhou, Y.; Han, Y.; Yang, R. Ca ${ }^{2+}$ involved in GABA signal transduction for phenolics accumulation in germinated hulless barley under $\mathrm{NaCl}$ stress. Food Chem. X 2019, 2, 100023. [CrossRef]

116. Liu, J.; Niu, Y.; Zhang, J.; Zhou, Y.; Ma, Z.; Huang, X. $\mathrm{Ca}^{2+}$ channels and $\mathrm{Ca}^{2+}$ signals involved in abiotic stress responses in plant cells: Recent advances. Plant Cell Tissue Organ Cult. 2017, 132, 413-424. [CrossRef]

117. Fan, G.; Jian, D.; Sun, M.; Zhan, Y.; Sun, F. Endogenous and exogenous calcium involved in the betulin production from submerged culture of phellinus linteus induced by hydrogen sulfide. Appl. Biochem. Biotechnol. 2016, 178, 594-603. [CrossRef]

118. Valivand, M.; Amooaghaie, R.; Ahadi, A. Seed priming with $\mathrm{H}_{2} \mathrm{~S}$ and $\mathrm{Ca}\left({ }^{2+}\right)$ trigger signal memory that induces cross-adaptation against nickel stress in zucchini seedlings. Plant Physiol. Biochem. 2019, 143, 286-298. [CrossRef]

119. Jia, H.; Hu, Y.; Fan, T.; Li, J. Hydrogen sulfide modulates actin-dependent auxin transport via regulating ABPs results in changing of root development in Arabidopsis. Sci. Rep. 2015, 5, 8251. [CrossRef] 